\title{
Aquecendo os motores para o XXVI Congresso Brasileiro de Cefaleia
}

\section{$\mathcal{N}_{0.0}$} artigos que certamente proporcionará uma leitura agradável e proveitosa. Além do relato original descrevendo um levantamento sobre cefaleia e alodinia em um grande grupo de indivíduos, realizado pela equipe da Universidade Federal de Pernambuco, temos um artigo de pesquisa histórica cujo tema é a fundação da nossa Sociedade Brasileira de Cefaleia, escrito pelo colega Silva-Néto - que vem tornando-se a referência para quem busca conhecer a história da cefaliatria brasileira e seus fundadores. A sessão Neuroarte traz a visão de um artista de rua sobre a migrânea, sendo muito interessante a concordância da imagem desenhada por ele com o quadro clínico habitual da migrânea, em contraponto com a sua compreensão enviesada - ao nosso ver - sobre a natureza do sintoma cefaleia. Os artigos de revisão nos permitem "absorver" o estado-da-arte em três assuntos de grande importância: cefaleia e gravidez, cefaleia e melatonina e neuralgia do trigêmeo \& dor facial persistente idiopática. Os dois primeiros, escritos, respectivamente, por André Gonçalves, Reinaldo Ribeiro e Mário Peres e por Eliana Melhado e Andressa Galego, mostram os frutos do estudo aprofundado de alguns temas específicos por colegas da SBCe, compartilhados com a comunidade cefaliátrica nesta publicação. $\bigcirc$ último é a benvinda contribuição de um dos grupos de maior destaque da cefaliatria mundial, o grupo da Universidade de Duisburg-Essen, que nos oferece uma revisão aprofundada, e ao mesmo tempo voltada para a prática clínica, destes dois temas.

Não podemos deixar de citar a proximidade do XXVI Congresso Brasileiro de Cefaleia, que terá lugar na fantástica cidade do Rio de Janeiro, em setembro próximo - acreditamos que esta edição da Headache Medicine será um bom aperitivo para os tradicionais três dias de intensa aquisição de conhecimento e troca de experiências que caracterizam os encontros anuais da nossa SBCe.

\section{Warming-up for the XXVI Brazilian Headache Congress}

$T_{n}$ this Headache Medicine 2012 second number, the reader will find a set of papers that will certainly ensure a pleasant and fruitful reading. Besides an original work that describes headache and allodynia association in a large group, made by Universidade Federal de Pernambuco team, we have a historic research article, written by Silva-Néto - who is becoming the reference for those who want to know the history of the Brazilian Headache Society and its founders. The Neuroart section brings the point of view of a street artist on headache and the intriguing harmony between his drawing and migraine usual clinical presentation, in opposition to his biased understanding in our view - about the nature of head pain. The review articles allow us to "absorb" the state-of-art of three extremely important subjects: headache and pregnancy, headache and melatonin and trigeminal neuralgia \& persistent idiopathic facial pain. The two first, written respectively by André Gonçalves, Reinaldo Ribeiro, Mário Peres and by Eliana Melhado and Andressa Galego, are representative of the profound dedication to specific headache fields by some Brazilian Headache Society members. The last one is a welcome contribution from the Duisburg-Essen University group, one of the most prominent of world headache, which offers a review at the same time profound and oriented to the clinical practice.

It is imperative to mention how close we are from the XXVI Brazilian Headache Congress, which will take place in the wonderful city of Rio de Janeiro in September - we think that this edition of Headache Medicine will be a good appetizer to the traditional three days of intense acquisition of knowledge and experiences exchange that characterize SBCe annual meetings.

Fernando Kowacs \& Marcelo Moraes Valença 